\title{
Biologically active peptides derived from the Antarctic hydrobionts
}

\author{
Nataliia Raksha ${ }^{1 *}$, Tetiana Halenova ${ }^{1}$, Tetiana Vovk ${ }^{1}$, Olexiy Savchuk ${ }^{1}$, Viktor Tomchuk ${ }^{2}$, Tetiana Maievska ${ }^{3}$, \\ Ludmila Ostapchenko ${ }^{1}$ \\ 'Department of Biochemistry, Taras Shevchenko National University, Kyiv, Ukraine \\ ${ }^{2}$ Department of Biochemistry and Physiology of Animals, National University of Life and Environmental Sciences of Ukraine, Kyiv, Ukraine \\ ${ }^{3}$ Ukrainian's Fishing Industry Cluster of Innovations, Kyiv, Ukraine
}

\section{ARTICLE INFO \\ Received on: 07/03/2021 \\ Accepted on: 18/05/2021 \\ Available online: 05/08/2021}

\section{Key words:}

Antarctic hydrobionts, antioxidant activity, membrane-protective activity, thrombin activity, fibrinogen polymerization.

\begin{abstract}
The development of novel, more efficient antioxidants is one of the most perspective approaches for the treatment of diseases related to oxidative stress. Due to their numerous beneficial health effects, antioxidant peptides draw significant research attention. The aim of this study was to investigate the antioxidant potential of the peptides derived from the Antarctic hydrobionts and the effect of the peptides on key factors of blood clotting. The peptide fractions were isolated from the tissue of the Antarctic hydrobionts by sequential precipitation with perchloric acid and ethanol. All hydrobionts have peptides with antioxidant activity, but their effectiveness is different for different species. The peptides of Antarctic krill are effective at scavenging 1,1-diphenyl-2-picrylhydrazyl radicals, superoxide anion radicals, and nitric oxide radicals, while the peptides of Antarctic jellyfish exhibit metal-chelating ability and hydrogen peroxide scavenging activity. The peptides of Antarctic limpet possess hydroxyl radical scavenging activity and provide a slight membrane-protective activity. In addition, the peptides derived from the Antarctic hydrobionts decreased the amidolytic activity of thrombin and increased the ability of thrombin to polymerize the fibrinogen. Obtained results showed that natural peptides of the Antarctic hydrobionts possess various types of biological activities and can be used as antioxidants or molecules affecting blood coagulation.
\end{abstract}

\section{INTRODUCTION}

Free radicals are fundamental to living organisms and represent an essential part of metabolism. At the physiological level, free radicals are important as signaling or defense molecules (Droge, 2002; Silva and Coutinho, 2010). An imbalance between the formation and elimination of free radicals potentially leads to cellular damage, resulting in the development of pathologies associated with oxidative and nitrosative stresses (Bahorun et al., 2006; Christen, 2000). Therefore, the decrease of free radical level is probably one of the most effective ways to protect cells against oxidative damage. In this case, the timely intake of antioxidant supplements or food containing antioxidants may reduce the risk of oxidative damage and prevent disease progression. According to recent research, synthetic antioxidants can induce DNA

\section{"Corresponding Author}

Nataliia Raksha, Department of Biochemistry, Taras Shevchenko National University, Kyiv, Ukraine.E-mail:nkudina@ukr.net damage and toxicity, and therefore their usage should be strictly limited (Ju et al., 2019). Additionally, the increase of consumers' awareness about the direct link between diet and health has raised the demand for functional food enriched in antioxidants and nutraceuticals. Therefore, there is research interest in the discovery of natural antioxidants with little or no side effects as alternatives to synthetic products.

Antioxidant peptides draw significant research attention because of their numerous beneficial health effects. They are safe, quite stable, and easily absorbed, and their low molecular weight excludes the development of immune response. Antioxidant peptides may serve as functional ingredients to enhance food safety and increase the shelf-life of food, thereby reducing the need for synthetic antioxidants. The common approaches to obtain bioactive peptides include acid, alkaline hydrolysis, or enzymatic hydrolysis with appropriate proteolytic enzymes. Peptides with antioxidant activity have been produced from various protein sources such as milk protein (Pihlanto, 2006), porcine hemoglobin (Chang et al., 2007), egg yolk protein (Davalos et al., 2004), soybean protein (Beermann et al., 2009), 
and rice bran protein (Adebiyi et al., 2007). Marine organisms tend to be a promising material for peptide production. Peptides obtained as a result of hydrolysis of the tissue of hydrobionts have many activities, including antibacterial, anticoagulant, antitumor, and immunomodulatory (Donia and Hamann, 2003; Martins et al., 2014). However, only a few reports have been dedicated to the investigation of naturally occurring antioxidant peptides (Liu et al., 2015). In recent years, special attention is paid to the hydrobionts from the Antarctic region, which are poorly explored and potentially can be a valuable source of new bioactive compounds. These organisms live in quite extreme conditions in adapting to that they produce a wide variety of biologically active substances. In our previous studies (Raksha et al., 2019), we found that the peptides obtained by enzymatic hydrolysis of the tissue of the Antarctic hydrobiont Adamussium colbecki exert a protective effect on the activity of antioxidant enzymes, reduce the level of oxidative modification of proteins and lipid peroxidation products, and preserve the level of protein and nonprotein sulfhydryl groups. So, the current research aimed to isolate the natural peptides from the tissue of the Antarctic hydrobionts and to test the peptide fractions for antioxidant activity. The additional task was to investigate the influence of peptide fractions on some coagulation factors. Our interest in the search for peptides able to influence hemostasis arose from the fact that thromboembolic diseases are recognized as the leading cause of mortality in the world. Maintaining an appropriate ratio between bleeding and clotting is undoubtedly important as a derangement of coagulation is typical for many pathological conditions. Although several anticoagulants are actively used to treat thrombotic conditions, most of them have some undesirable side effects. Therefore, there is an urgent need to search for natural compounds with fewer side effects that could affect the coagulation factors.

\section{MATERIALS AND METHODS}

\section{Reagents}

Phenazinemethosulfate, nitrobluetetrazolium, 1,1-diphenyl2-picrylhydrazyl radical, ascorbic acid, nicotinamide adenine dinucleotide reduced (NADH), 2-deoxyribose, ferrous ammonium sulfate, ethylenediaminetetraacetic acid (EDTA), thiobarbituric acid, trichloroacetic acid, sodium nitroprusside, 1,10-phenanthroline, Griess reagent, tris(hydroxymethyl)aminomethane, sodium azide, and hydrogen peroxide were purchased from Sigma-Aldrich (St. Louis, MO). Thrombin and chromogenic substrate H-D-Phe-PipArg-pNA were purchased from Renam (Moscow, Russia). All other chemicals and reagents used in this study were of analytical grade quality and available commercially.

\section{Hydrobionts collection}

The specimens of hydrobionts Antarctic limpet (Nacella concinna), Antarctic krill (Euphausia superba), and Antarctic jellyfish (Diplulmaris antarctica) $(n=35$ for each species) were collected near the island Galindez (geographical coordinates: $65^{\circ} 15^{\prime}$ south latitude and $64^{\circ} 15^{\prime}$ west longitude) of Argentine Islands. The materials were collected by the XVII (March 2012-April 2013) and XVIII (March 2013-April 2014) Ukrainian Antarctic expeditions. After collection, the hydrobionts were immediately frozen in liquid nitrogen to prevent enzyme deterioration and stored at $-80^{\circ} \mathrm{C}$. The samples were transported to the laboratory frozen. The hydrobionts were authenticated by the Department of Zoology and Ecology (ESC "Institute of Biology and Medicine" of Taras Shevchenko National University of Kyiv, Ukraine).

\section{Isolation of the peptide fraction}

The frozen mass of the soft tissues of the hydrobionts was weighed and then was powdered with the addition of liquid nitrogen. The powder was suspended in the extraction buffer (Trisbuffered saline, $\mathrm{pH} 7.4,1 \mathrm{mM}$ EDTA, $0.25 \%$ sucrose, and $0.5 \%$ Triton X-100) at the ratio of $1: 2, w / v$, and was stirred continuously at $4^{\circ} \mathrm{C}$ for 30 minutes. Afterwards, the sample was centrifuged (Allegra 64 R Centrifuge, Beckman Coulter, Fullerton, CA) at $10,000 \mathrm{~g}$ for 30 minutes at $4^{\circ} \mathrm{C}$. The peptide fraction was isolated according to the method described by Nikolajchik et al. (1991).

\section{Estimation of antioxidant activity of the peptides derived from the Antarctic hydrobiont}

Samples of the lyophilized peptides were dissolved in $20 \%$ ethanol at a concentration of $2 \mathrm{mg}$ per $\mathrm{ml}$.

Ascorbic acid at the concentration of $0.1 \mathrm{mM}$ was used as the positive control in the determination of hydrogen peroxide scavenging activity, nitric oxide scavenging activity, metalchelating ability, and reducing power. About $5 \mathrm{mM}$ of ascorbic acid and $0.5 \mathrm{mM}$ of ascorbic acid were used as the positive control in the determination of 1,1-diphenyl-2-picrylhydrazyl radical (DPPH) scavenging activity and superoxide anion radical scavenging activity of the peptide fraction.

\section{DPPH scavenging activity assay}

The free radical scavenging activity of the peptides was tested by their ability to scavenge the stable DPPH (Rice-Evans et al., 1995). The peptide fraction $(100 \mu \mathrm{g})$ was mixed with DPPH $(0.15 \mathrm{mM})$. The mixture was kept in the dark at room temperature for 30 minutes and the absorbance of the sample was measured at $517 \mathrm{~nm}$.

\section{Hydrogen peroxide scavenging activity assay}

The hydrogen peroxide scavenging activity of the peptide fraction was measured according to the method reported by Hadwan and Abed (2016). The peptide fraction $(100 \mu \mathrm{g})$ was mixed with hydrogen peroxide $(0.05 \%)$ and incubated for 10 minutes at room temperature. After adding ammonium molybdate $(1.5 \%)$, the absorbance of the samples was measured at $410 \mathrm{~nm}$.

\section{Superoxide anion radical scavenging activity assay}

The superoxide anion radical scavenging activity of peptides was assessed as described by Liu et al. (1997). The superoxide anion radicals are generated in $0.1 \mathrm{M}$ Tris- $\mathrm{HCl}$ buffer, $\mathrm{pH} 8.0$, containing NADH $(0.8 \mathrm{mM})$, phenazine methosulfate $(0.02 \mathrm{mM})$, and the peptide fraction $(100 \mu \mathrm{g})$. The reaction was started by the addition of nitroblue tetrazolium $(0.1 \mathrm{mM})$. After 5 minutes incubation at room temperature, the absorbance of the samples was read at $560 \mathrm{~nm}$.

\section{Hydroxyl radical scavenging activity assay}

The hydroxyl radical scavenging activity of peptides was determined according to the method described by Siddhuraju and Becker (2007). The peptide fraction $(100 \mu \mathrm{g})$ was mixed 
with 2-deoxyribose $(3 \mathrm{mM})$, ferrous ammonium sulfate $(0.1$ $\mathrm{mM})$, and EDTA $(0.1 \mathrm{mM})$. The reaction was initiated by the addition of hydrogen peroxide $(0.5 \mathrm{mM})$ and ascorbic acid $(0.1$ $\mathrm{mM}$ ); the samples were incubated at $37^{\circ} \mathrm{C}$ for 15 minutes. Then, thiobarbituric acid solution $(0.3 \%)$ and trichloroacetic acid (5\%) were added to the samples. The mixture was boiled in a water bath for 15 minutes and cooled in ice; the absorbance of the samples was measured at $532 \mathrm{~nm}$.

\section{Nitric oxide radical scavenging activity assay}

Nitric oxide radical scavenging activity of peptides was determined according to the method reported by Royer et al. (2011). The reaction mixture contained sodium nitroprusside (5 $\mathrm{MM}$ ) in $0.1 \mathrm{M}$ phosphate-buffered saline, $\mathrm{pH} 7.4$, and the peptide fraction $(100 \mu \mathrm{g})$. After incubation at room temperature for 120 minutes, Griess reagent (5\%) was added and the absorbance of the samples was measured at $546 \mathrm{~nm}$. The percentage of DPPH scavenging activity, hydrogen peroxide scavenging activity, superoxide anion radical scavenging activity, hydroxyl radical scavenging activity, and nitric oxide radical scavenging was calculated as follows:

\section{$S-K S \times 100 \%$}

where $K$ is the absorbance of the control sample. The control sample contains $20 \%$ alcohol instead of the peptide fraction. $S$ is the absorbance of the peptide sample.

\section{Reducing power assay}

The reducing power of the peptides was evaluated by the method described by Rice-Evans et al. (1995). The reaction mixture contained the peptide fraction $(100 \mu \mathrm{g})$, potassium ferricyanide $(0.5 \%)$, and $0.2 \mathrm{M}$ sodium phosphate buffer, $\mathrm{pH}$ 6.6. The mixture was incubated at $50^{\circ} \mathrm{C}$ for 30 minutes and the reaction was terminated by the addition of trichloroacetic acid (5\%). After centrifugation at 5,000 g for 10 minutes, the upper layer was mixed with an equal volume of distilled water and ferric chloride $(0.1 \%)$. The absorbance of the sample was measured at $700 \mathrm{~nm}$. The reducing power was calculated as follows:

\section{$S-K S \times 100 \%$}

where $K$ is the absorbance of the control sample. The control sample contains $20 \%$ alcohol instead of the peptide fraction. $S$ is the absorbance of the peptide sample.

\section{Metal-chelating ability assay}

The metal-chelating ability of peptides was measured according to the method reported by Wang et al. (2013) with minor modification. The reaction mixture consisted of the peptide fraction $(100 \mu \mathrm{g})$, ferrous sulfate $(0.2 \mathrm{mM})$, hydrogen peroxide $(0.01 \%)$, and $0.2 \mathrm{M}$ sodium phosphate buffer, $\mathrm{pH}$ 7.8. After 15 minutes incubation, 1,10 -phenanthroline $(0.2 \mathrm{mM})$ was added to the sample solution. The absorbance of the sample was read at $560 \mathrm{~nm}$. The percentage of metal-chelating ability was calculated as follows:

\section{$S-K B-S \times 100 \%$}

where $K$ is the absorbance of the control sample. The control sample contains $20 \%$ alcohol instead of the peptide fraction. $S$ is the absorbance of the peptide sample. $B$ is the absorbance of the blank sample. The blank sample contains 20\% alcohol and distilled water instead of the peptide fraction and hydrogen peroxide, respectively.

\section{Estimation of membrane-protective activity of the peptides derived from the Antarctic hydrobiont}

Suspension of rabbit erythrocytes was prepared to evaluate the membrane-protective activity of peptides. All experiments on animals were performed in compliance with international principles of the European Convention for the protection of vertebrate animals used for experimental and other scientific purposes (available at: https:/www.coe.int/en/web/ conventions/full-list/-/conventions/treaty/123). The study was approved by the Ethical Committee of the Taras Shevchenko National University of Kyiv. Blood was collected from the rabbit ear artery in the tubes containing 3.8\% sodium citrate to prevent coagulation and centrifuged at $500 \mathrm{~g}$ for 10 minutes at $4^{\circ} \mathrm{C}$. Plasma was removed carefully and erythrocytes were then washed for additional three times in phosphate-buffered saline, $\mathrm{pH}$ 7.2. The membrane-protective activity was evaluated according to the method reported by Mendanha et al. (2012). To evaluate the protective effect of peptides, erythrocytes were incubated for 30 minutes at $37^{\circ} \mathrm{C}$ with the peptide fractions at concentrations of $100 \mu \mathrm{g}$ per $\mathrm{ml}$ of the erythrocyte suspension. Oxidative stress was then induced in the erythrocyte suspension $(2 \%, v / v)$ with $5 \mathrm{mM}$ hydrogen peroxide. The samples were incubated at $37^{\circ} \mathrm{C}$ for 3 hours. Sodium azide $(1 \mathrm{mM})$ was added to the samples to prevent the destruction of hydrogen peroxide by catalase. After incubation, the samples were centrifuged for 6 minutes at 2,500 $\mathrm{g}$ and the supernatants were used to measure the absorbance of the liberated hemoglobin at $541 \mathrm{~nm}$. Untreated erythrocytes were taken as the negative control. Erythrocytes incubated with $5 \mathrm{mM}$ hydrogen peroxide were taken as the positive control. Assays were performed in triplicates using red blood cells from three different rabbits.

\section{Estimation of the effect of Antarctic hydrobiont peptides on thrombin activity and fibrinogen polymerization}

Lyophilized peptide samples were dissolved in Trisbuffered saline, $\mathrm{pH} 7.4$, at a concentration of $2 \mathrm{mg}$ per $\mathrm{ml}$ of buffer. Thrombin was diluted in $0.9 \%$ sodium chloride to a concentration of 0.1 U. Fibrinogen was diluted in Tris-buffered saline, $\mathrm{pH} 7.4$, to a concentration of $1 \mathrm{mg}$ per $\mathrm{ml}$ of buffer.

\section{Determination of the amidolytic activity of thrombin}

To evaluate the effect of peptides on the amidolytic activity of thrombin, the active thrombin was preincubated in Trisbuffered saline, $\mathrm{pH} 7.4$ at the presence of peptide fraction (10 or $0.1 \mu \mathrm{g}$ ) (Halenova et al., 2020). After 15 minutes of incubation at room temperature, the chromogenic substrate H-D-Phe-Pip-ArgpNA $(0.3 \mathrm{mM})$ was added to the reaction mixture. The change in the absorbance was recorded for 1 hours at a $405 \mathrm{~nm}$ wavelength.

\section{The measurement of thrombin-induced fibrinogen polymerization}

Fibrinogen was obtained from blood plasma by precipitation with $16 \%$ ammonium sulfate followed by 
cryofibrinogen separation according to the method (Varetskaya, 1960). In the first case, the fibrinogen $(100 \mu \mathrm{g})$ in $50 \mathrm{mM}$ Trisbuffered saline, $\mathrm{pH} 7.4$, was preincubated with the peptides (100 $\mu \mathrm{g})$ in the wells of a 96-well plate. After 15 minutes of incubation at room temperature, the thrombin was added to the reaction mixture. In the second case, thrombin in $50 \mathrm{mM}$ Tris-buffered saline, $\mathrm{pH} 7.4$, was preincubated with the peptides $(100 \mu \mathrm{g})$ in a 96-well plate. After 15 minutes of incubation at room temperature, the fibrinogen $(100 \mu \mathrm{g})$ was added to the reaction mixture. The change in the absorbance was recorded for 1 hours at a $595 \mathrm{~nm}$ wavelength.

\section{Statistical analysis}

The statistical analysis was carried out by using the Statistical Package for Social Sciences $(11.0,2001)$ software. The data were expressed as mean $\pm \mathrm{SD}(n=5)$.

\section{RESULTS AND DISCUSSION}

\section{The antioxidant activity of peptides derived from the Antarctic hydrobionts}

Considering the complexity of oxidative processes taking place in biological systems, as well as the different mechanisms by which compounds may realize their activities, using a single method to evaluate the antioxidant potential of a compound is not a suitable approach. Therefore, in the current study, various types of assays have been used to assess the antioxidant activity of the peptides derived from hydrobionts of the Antarctic region.

At first, the total antioxidant activity of peptides was assessed. Obtained data revealed that the peptides from the tissue of the Antarctic hydrobionts can scavenge DPPH radicals but with different efficiency (Table 1). The peptides from the tissue of Antarctic krill had the most pronounced ability to scavenge the DPPH radical (36\%), which may indicate that krill peptides are potential antioxidant compounds. Our results are similar to those reported by Safari and Yaghoubzadeh (2020); Yu et al. (2018) who evaluated the DPPH scavenging activity of the peptides extracted from sea cucumber (Holothuria leucospilota) and mollusk (Ruditapes philippinarum), respectively. The percentage of inhibition of DPPH by the peptides from Antarctic jellyfish and Antarctic limpet was $10 \%$ and $7.5 \%$, respectively. It should be noted that the scavenging activity of ascorbic acid, which was used as the positive control, was significantly more pronounced $(98 \%)$ than those of the tested peptide fractions.
There are several reports (Jayaprakash et al., 2001; Spiegel et al., 2020) that have demonstrated that the degree of reducing the activity of a substance is strongly associated with its antioxidant potential. Compound with high reducing activity is considered to have a better ability to donate electrons and, therefore, can act as powerful antioxidants. According to the obtained data, Antarctic krill peptides showed the highest reducing activity among the tested peptide fractions (Table 1). The reducing activity of the peptides derived from krill was $64 \%$, while the reducing power of ascorbic acid was found to be only $3 \%$. These values for Antarctic jellyfish peptides and Antarctic limpet peptides were $2.5 \%$ and $6 \%$, respectively. In general, the obtained results were in agreement with the results of the DPPH assay.

Despite the essential role of iron for vital activity, namely its participation in oxygen transport, respiration, and maintaining the activity and stability of many enzymes, an increase in the level of this metal can provoke oxidative stress (Puntarulo, 2005). Therefore, removing ferrous ions may be one possible way to reduce oxidative stress and protect cells from damage caused by free radicals. Given the above, the metal-chelating ability of the peptide fractions was investigated. All peptide samples were found to have a low ability to chelate ferrous ions. The peptides derived from Antarctic jellyfish had a higher ferrous ion chelating ability (13\%) compared with peptides from other hydrobionts $(1.5 \%$ for the peptides from Antarctic limpet and 3\% for the peptides from Antarctic krill). Ascorbic acid that was used as the positive control showed a significant effect (89\%).

The antioxidant potential of peptides was also assessed by their hydrogen peroxide scavenging ability. Although hydrogen peroxide is a weak oxidizing agent, it can be quite hazardous (Halliwell et al., 2000). Being a nonreactive molecule, hydrogen peroxide can move on considerable distances, cross biological membranes leading to the distribution and generalization of oxidative stress. The obtained results indicated that peptides derived from the tissue of the Antarctic hydrobionts may act as scavengers of hydrogen peroxide. The peptides from Antarctic jellyfish showed higher scavenging activity (14\%) than other peptide fractions; no significant difference was found between the effect of the peptides from Antarctic limpet (8.3\%) and Antarctic krill $(10.5 \%)$.

Due to high reactivity, hydroxyl radicals are the most dangerous radicals (Davies, 2000). They cause severe oxidative damage to nucleic acids, lipids, and proteins. Therefore, the removal of hydroxyl radicals is of great importance in preventing

Table 1. Antioxidant activity (\%) of the peptide fraction derived from the Antarctic hydrobionts.

\begin{tabular}{|c|c|c|c|c|}
\hline \multirow{2}{*}{ Type of activity } & \multirow{2}{*}{ Ascorbic acid } & \multicolumn{3}{|c|}{ Hydrobiont } \\
\hline & & Antarctic limpet & Antarctic krill & Antarctic jellyfish \\
\hline DPPH radical scavenging activity & $98.0 \pm 4.90$ & $7.5 \pm 0.33$ & $36.0 \pm 1.67$ & $10.0 \pm 0.5$ \\
\hline Reducing activity & $3.0 \pm 0.15$ & $6.0 \pm 0.25$ & $64.0 \pm 3.10$ & $2.5 \pm 0.12$ \\
\hline Metal-chelating ability & $89.0 \pm 4.20$ & $1.5 \pm 0.07$ & $3.0 \pm 0.18$ & $13.0 \pm 0.63$ \\
\hline Hydrogen peroxide scavenging activity & $57.0 \pm 2.80$ & $8.3 \pm 0.25$ & $10.5 \pm 0.51$ & $14.8 \pm 0.72$ \\
\hline Superoxide anion radical scavenging activity & $55.0 \pm 2.73$ & $3.0 \pm 0.11$ & $20.0 \pm 0.98$ & $2.3 \pm 0.11$ \\
\hline Hydroxyl radical scavenging activity & $80.0 \pm 4.10$ & $12.0 \pm 0.60$ & $0.8 \pm 0.04$ & $1.0 \pm 0.04$ \\
\hline Nitric oxide radical scavenging activity & $4.6 \pm 0.21$ & $16.0 \pm 0.75$ & $34.0 \pm 1.65$ & $1.2 \pm 0.07$ \\
\hline
\end{tabular}

Values are expressed as the mean $\pm \mathrm{SD}(n=5)$. 
pathological conditions associated with the accumulation of free radicals. Current research has shown that only the peptides derived from Antarctic limpet have hydroxyl radical scavenging activity. Hydroxyl radical scavenging activity of limpet peptides was $15 \%$ in contrast to $80 \%$ for ascorbic acid.

In addition, the scavenging effect of peptides on superoxide radicals was estimated. These radicals are not only highly reactive but also can be precursors of the more reactive oxygen species especially hydroxyl radicals. According to the results, only peptides derived from Antarctic krill showed the scavenger potential on superoxide anion radicals. The superoxide anion radical scavenging activity of krill peptides reached $20 \%$ compared with $55 \%$ in the case of ascorbic acid. The ability of the peptides from Antarctic limpet and Antarctic jellyfish to scavenge superoxide radicals was about $3 \%$.

In general, the ability of the peptides from the Antarctic hydrobionts to scavenge hydroxyl radical and superoxide radicals was lower than that of the protein hydrolysates obtained from other species, such as flying squid (Ommastrephes bartramii) (Chen et al., 2010), tuna (Thunnus spp.) (Aleman et al., 2011), horse mackerel (Megalaspis cordyla) (Kumar et al., 2011), and jellyfish (Rhopilema esculentum) (Zhuang et al., 2009).

Nitric oxide is an effector molecule produced in mammalian cells and involved in the regulation of various physiological processes (Antosova et al., 2017). However, excess production of NO leads to serious complications (Costa et al., 2016). The toxic effect of NO is enhanced in the reaction with superoxide radical through the formation of a second reactive compound peroxynitrite anion. In our study, Antarctic krill peptides effectively reduced the generation of nitric oxide from sodium nitroprusside. They showed stronger activity (33\%) than other peptide fractions (16\% for Antarctic limpet peptides and near $2 \%$ for Antarctic jellyfish peptides).

The membrane-protective properties of the peptides derived from the Antarctic hydrobionts

The integrity of erythrocytes was measured by the level of erythrocytes hemolysis. The effects of peptides on the hemolysis of erythrocytes were shown in Figure 1. Oxidative stress induced by hydrogen peroxide caused significant hemolysis of erythrocytes, which was $1.03 \pm 0.05$ versus $0.05 \pm 0.0025$ in the nontreated erythrocytes. Even though peptides from Antarctic krill were more effective in scavenging free radicals, these peptides did not show the ability to protect erythrocytes against oxidative damage. According to the data, only Antarctic limpet peptides had a slight protective effect against chemically induced hemolysis of erythrocytes. They reduce the level of erythrocytes hemolysis by $27 \%(p<0.05)$, while peptides from other hydrobionts were ineffective. It was also found that the Antarctic hydrobiont peptides did not show hemolytic activity that indirectly indicates their safety.

\section{The antithrombotic potential of the peptides derived from the Antarctic hydrobionts}

Given that the percentage of people suffering from thrombotic disorders is growing continuously, the search for effective anticoagulants is very relevant. Considering our previous results (Raksha et al., 2016a, 2016b) on the presence in the tissue

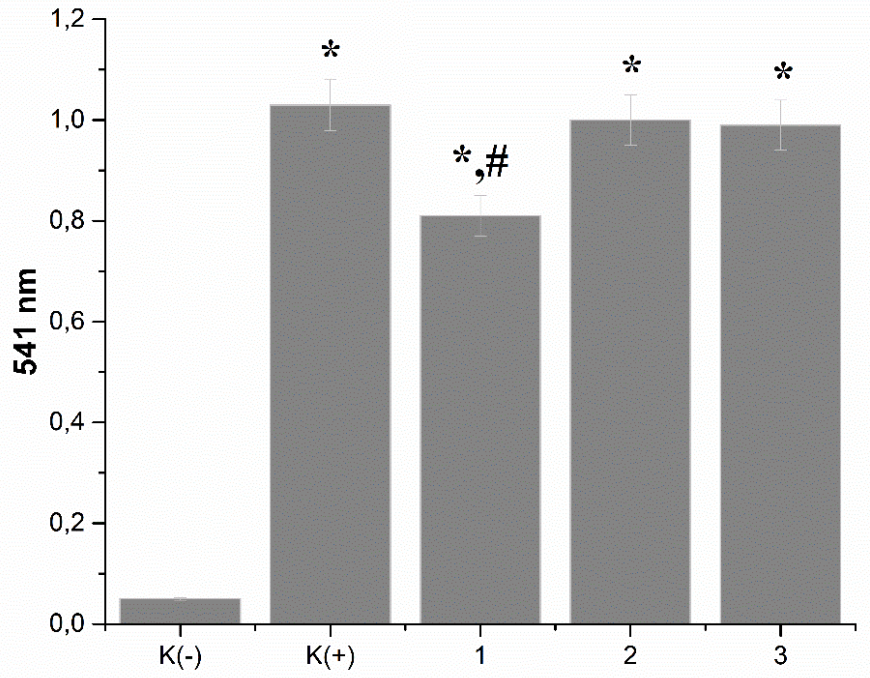

Figure 1. Effect of the peptides on the level of erythrocytes' hemolysis: $\mathrm{K}(-)$ : untreated erythrocytes; $\mathrm{K}(+)$ : erythrocytes incubated with $5 \mathrm{mM}$ hydrogen peroxide; 1: Antarctic limpet; 2: Antarctic krill; 3: Antarctic jellyfish. The peptides were tested at the concentration of $100 \mu \mathrm{g}$ per $1 \mathrm{~mL}$ of erythrocyte suspension. Data expressed as the optical density of samples at $541 \mathrm{~nm}$. Values are expressed as the mean $\pm \mathrm{SD}(n=5) .{ }^{*} p<0.05$, significantly different from $\mathrm{K}(-) ; \# p<0.05$, significantly different from $\mathrm{K}(+)$

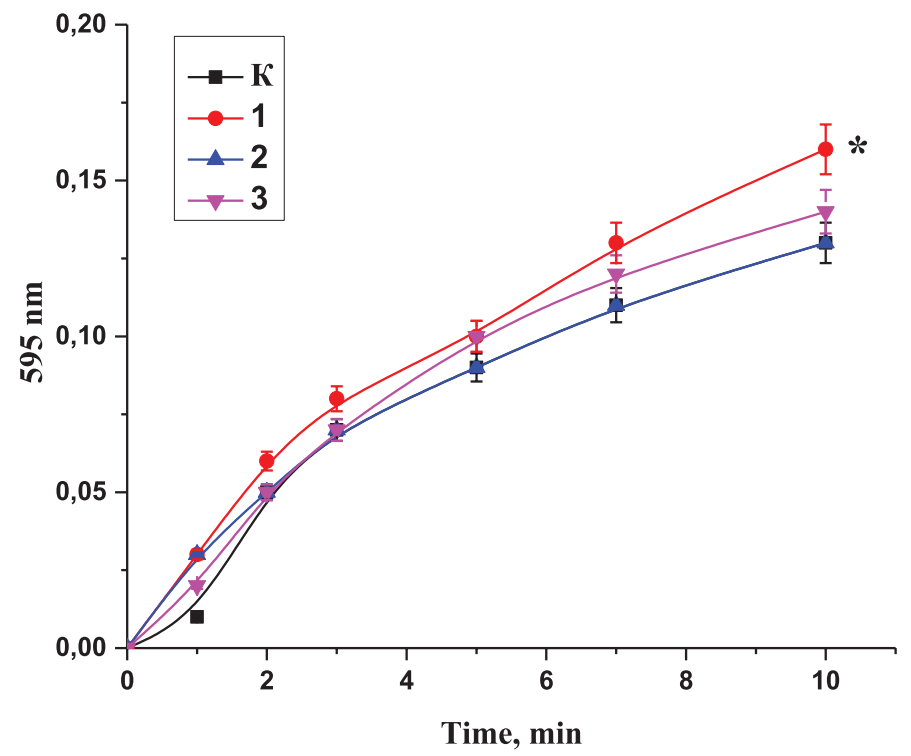

Figure 2. Effect of the peptides on the ability of fibrinogen to polymerize by thrombin: K: the control sample; 1 : Antarctic limpet peptides ${ }^{*} p<0.05$, significantly different from the control); 2: Antarctic krill peptides; 3: Antarctic jellyfish peptides. Data expressed as the optical density of samples at 595 $\mathrm{nm}$. The process of fibrinogen polymerization was initiated by the addition of thrombin $(0.1 \mathrm{U})$. Values are expressed as the mean $\pm \mathrm{SD}(n=5)$.

of the Antarctic hydrobionts the molecules that affect the main factors of hemostasis, we evaluated the antithrombotic potential of the peptides derived from the Antarctic hydrobionts.At first, the influence of peptides from the tissues of Antarctic hydrobionts on the ability of fibrinogen to polymerize was investigated. As can be seen from Figure 2, the preincubation of fibrinogen with the peptides before the addition of thrombin did not affect the 
polymerization; both the dynamic of the process and the extinction value were within the control level. A slight increase (by $23 \%, p<$ 0.05 ) in the sample's absorbance was found only after 10 minutes of the experiment in the case of preincubation of fibrinogen with Antarctic limpet peptides.

At the same time, our result indicated that incubation of the peptides with plasma before the addition of thrombin resulted in the enhancement of polymerization and formation of stronger thrombi. In the control sample, the curve reached a plateau after 20 minutes of the experiment, while in the samples containing peptides, after 10 minutes of the experiment. The effect of Antarctic krill peptides on thrombin-induced plasma polymerization was much more pronounced than the effect of the peptides derived from other hydrobionts (Fig. 3).

Taking into account the fact that thrombin is an ideal target for pharmacological correction, we analyzed the ability of the peptide fractions to affect the thrombin activity. Analyzing the literature, we found only a few reports on the study of the effect of peptides on thrombin activity (Cappello et al., 1996; Tanaka-Azevedo et al., 2010). It should be noted that there are no comprehensive studies regarding the effect of the peptides of the Antarctic hydrobionts on hemostasis parameters.

At the first stage of the study, we investigated whether the preincubation of the peptides with thrombin affected its ability to catalyze fibrinogen polymerization. According to obtained data (Fig. 4), the polymerization of fibrinogen was enhanced after the addition of thrombin that was preincubated for 15 minutes with the tested peptide fraction. The effects were similar for all peptide samples; the level of fibrinogen polymerization was increased compared with the controls. The absorbance of the sample after 10 minutes of the experiment was increased by $33 \%(p<0.05)$ in the case of incubation of thrombin with Antarctic limpet peptides and by $26 \%$ in the case of its incubation with the peptides derived from Antarctic krill or Antarctic jellyfish. It should be highlighted that

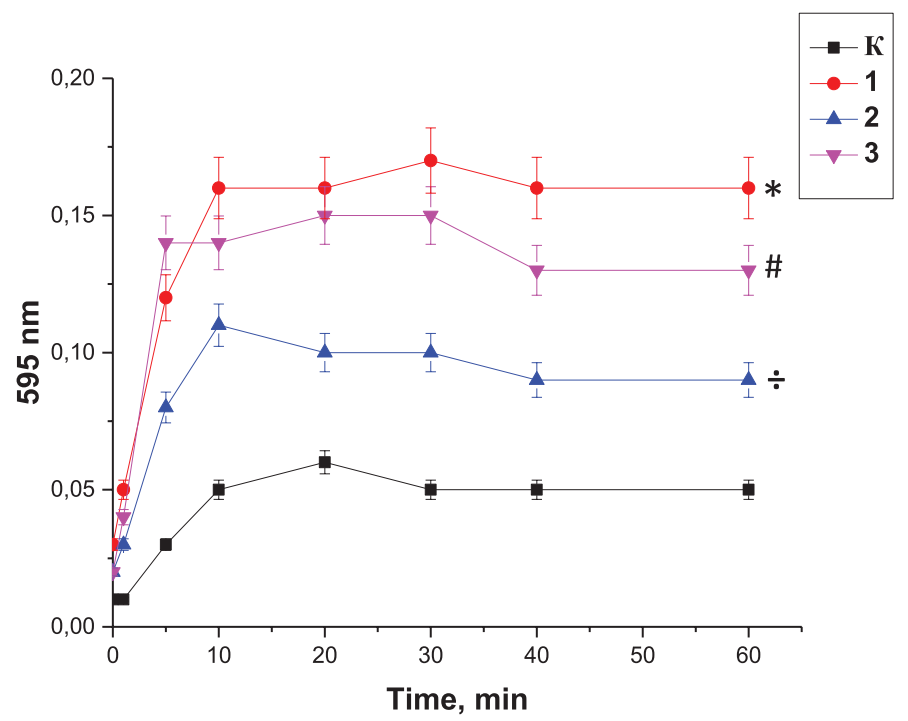

Figure 3. Effect of the peptides on the polymerization of blood plasma, preincubated with the peptides from the Antarctic hydrobionts: K: the control sample; 1: Antarctic limpet peptides $(* p<0.05$, significantly different from the control); 2: Antarctic krill peptides $(\div p<0.05$, significantly different from the control); 3: Antarctic jellyfish peptides ( $\neq p<0.05$, significantly different from the control). Data expressed as the optical density of samples at $595 \mathrm{~nm}$. The process of polymerization was initiated by the addition of thrombin $(0.1 \mathrm{U})$. we used peptide fractions that potentially consist of structurally different molecules. It is conceivable that peptides may bind to thrombin not only at the active site but also at other sites. Based on this fact we suggest that the binding of peptides to thrombin provokes some alterations in thrombin secondary structure facilitating the interaction of fibrinogen with the enzyme.

Next, the effect of the peptides on the amidolytic activity of thrombin was analyzed. It was found that peptides derived from the tissues of Antarctic jellyfish (Fig. 5) and Antarctic krill (Fig. 6)

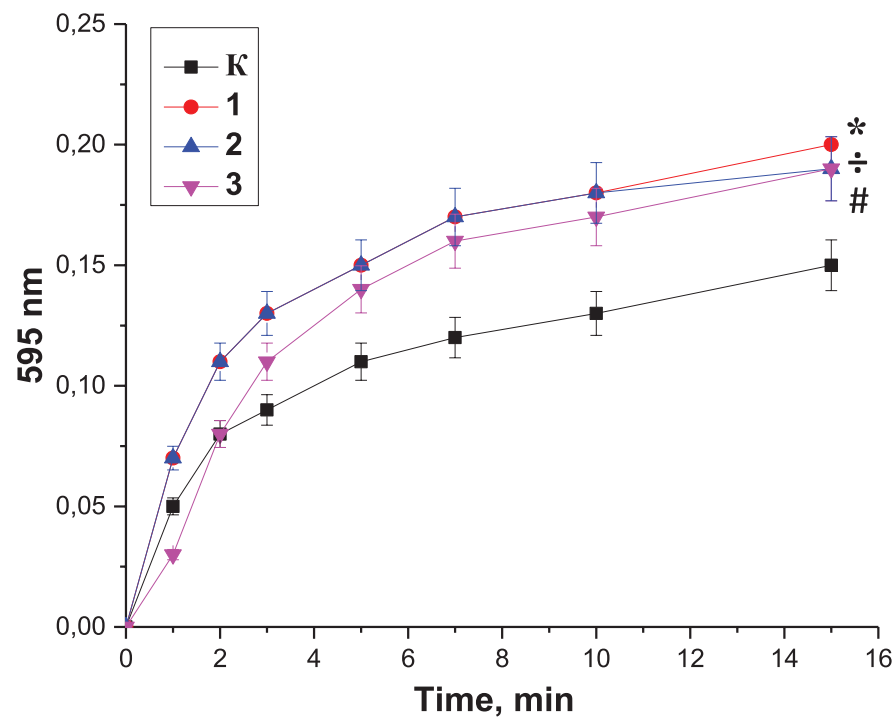

Figure 4. Effect of the peptides on the ability of thrombin to polymerize the fibrinogen: K: the control sample; 1: Antarctic limpet peptides ${ }^{*} p<0.05$, significantly different from the control); 2 : Antarctic krill peptides $(\div p<0.05$, significantly different from the control); 3 : Antarctic jellyfish peptides $(\neq p<$ 0.05 , significantly different from the control). Data expressed as the optical density of samples at $595 \mathrm{~nm}$. The process of polymerization was initiated by the addition of fibrinogen $(100 \mu \mathrm{g})$. Values are expressed as the mean $\pm \mathrm{SD}(n=$ 5). ${ }^{*} p<0.05$, significantly different from the control.

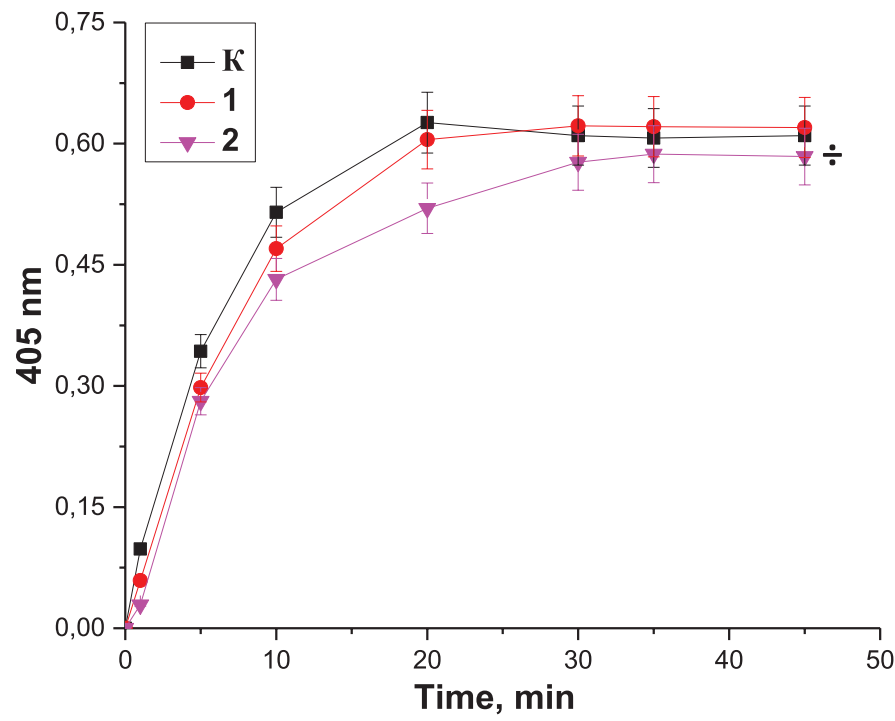

Figure 5. Effect of the peptides derived from Antarctic jellyfish on the amidolytic activity of thrombin: K: the control sample; 1 : the peptides at the concentration of $10 \mu \mathrm{g} ; 2$ : the peptides at the concentration of $0.1 \mu \mathrm{g}(\div p<0.05$, significantly different from the control). Data expressed as the optical density of samples at $405 \mathrm{~nm}$. Values are expressed as the mean $\pm \mathrm{SD}(n=5)$. 


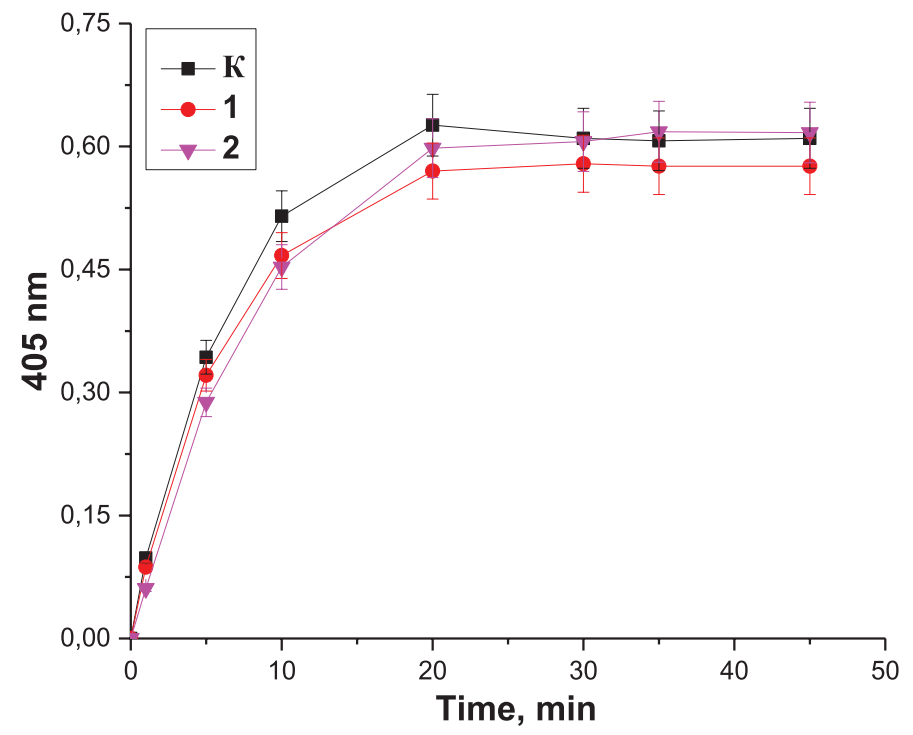

Figure 6. Effect of the peptides derived from Antarctic krill on the amidolytic activity of thrombin: K: the control sample; 1 : the peptides at the concentration of $10 \mu \mathrm{g} ; 2$ : the peptides at the concentration of $0.1 \mu \mathrm{g}$. Data expressed as the optical density of samples at $405 \mathrm{~nm}$. Values are expressed as the mean $\pm \mathrm{SD}$ $(n=5)$.

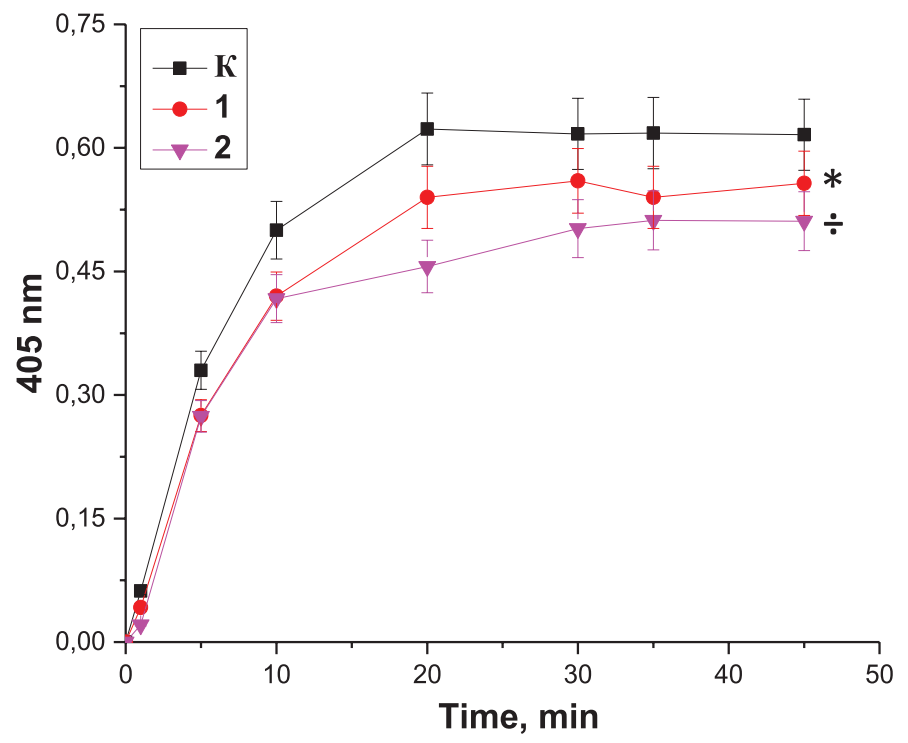

Figure 7. Effect of the peptides derived from Antarctic limpet on the amidolytic activity of thrombin: $\mathrm{K}$ : the control sample; 1 : the peptides at the concentration of $10 \mu \mathrm{g}(* p<0.05$, significantly different from the control by 5 and 10 minutes of the experiment); 2 : the peptides at the concentration of $0.1 \mu \mathrm{g}(\div p<0.05$, significantly different from the control). Data expressed as the optical density of samples at $405 \mathrm{~nm}$. Values are expressed as the mean $\pm \mathrm{SD}(n=5)$.

did not exert a significant effect on the amidolytic activity of thrombin. In contrast, preincubation of thrombin with the peptides from Antarctic limpet led to a decrease in the amidolytic activity of thrombin in a concentration-dependent manner (Fig. 7). We revealed that the lowest concentration of peptides contributed to more pronounced inhibition of thrombin activity. Antarctic limpet peptides at the concentration of 0.1 and 10 $\mu \mathrm{g}$ caused a decrease in the amidolytic activity of thrombin by $10 \%(p<0.05)$ and $20 \%(p<0.05)$, respectively. This allows us to consider Antarctic limpet as a promising source of possible thrombin inhibitors. The obtained results could be explained by the fact that some of the peptides may consist of arginine or lysine residues and therefore can compete with a synthetic substrate H-D-Phe-Pip-Arg-pNA for binding to the active site of thrombin. On the other hand, some peptides could form complexes with a chromogenic substrate, thus excluding its participation in the enzymatic reaction. It seems that the fraction of peptides derived from Antarctic limpet consists of molecules, some of which inhibit the amidolytic activity of thrombin, while others increase the ability of thrombin to catalyze fibrinogen polymerization. Marine-derived anticoagulant peptides have been isolated from a variety of sources, including yellowfin sole (Rajapakse et al., 2005), marine echiuroid worm (Jo et al., 2008), blue mussel (Jung et al., 2009), and ark shell (Jung et al., 2001). However, there are no reports of natural marine peptides that directly inhibit the amidolytic activity of thrombin by binding to its active site and blocking its enzymatic activity.

\section{CONCLUSION}

To the authors' knowledge, this is the first study dedicated to the comprehensive analysis of the biological activity of peptides derived from the Antarctic hydrobionts. Taken together, the findings from this study indicate that peptides of the Antarctic hydrobionts might be used as natural antioxidant supplements in the treatment of oxidative stress or/and in the prevention of oxidative damage of food products. The study showed that Antarctic limpet peptides possess antithrombotic activity, namely, inhibit the amidolytic activity of thrombin. It can be used in the development of the novel anticoagulant drug. Considering the obtained results, further experiments are required to obtain individual peptides and elucidate the mechanisms of their influence on thrombin activity.

\section{AUTHOR CONTRIBUTIONS}

All authors made substantial contributions to conception and design, acquisition of data, or analysis and interpretation of data; took part in drafting the article or revising it critically for important intellectual content; agreed to submit to the current journal; gave final approval of the version to be published; and agree to be accountable for all aspects of the work.

\section{ETHICAL APPROVALS}

The study was approved by the Ethical Committee of the Taras Shevchenko National University of Kyiv.

\section{PUBLISHER'S NOTE}

This journal remains neutral with regard to jurisdictional claims in published institutional affiliation.

\section{FUNDING}

None.

\section{REFERENCES}

Adebiyi A, Adebiyi A, Ogawa T, Muramoto K. Purification and characterisation of antioxidative peptides from unfractionated rice bran protein hydrolysates. Int J Food Sci Technol, 2007; 43:35-43.

Aleman A, Gimenez B, Montero P, Gomez-Guillen M Antioxidant activity of several marine skin gelatins. LWT Food Sci Technol, 2011; 44:407-13.

Antosova M, Mokra D, Pepucha L, Plevkova J, Buday T, Sterusky M, Bencova A. Physiology of nitric oxide in the respiratory system. Physiol Res, 2017; 66(2):S159-S172; doi:10.33549/physiolres.933673 
Bahorun T, Soobrattee M, Luximon-Ramma V, Aruoma O. Free radicals and antioxidants in cardiovascular health and disease. Int J Med, 2006; 1:1-17.

Beermann C, Euler M, Herzberg J, Stahl B. Anti-oxidative capacity of enzymatically released peptides from soybean protein isolates. Eur Food Res Technol, 2009; 229(4):637-44.

Cappello M, Bergum P, Vlasuk P, Furmidge B, Pritchard D, Aksoy S. Isolation and characterization of the tsetse thrombin inhibitor: a potent antithrombotic peptide from the saliva of Glossina morsitans morsitans. Am J Trop Med Hyg, 1996; 54(5):475-80.

Chang $\mathrm{C}, \mathrm{Wu} \mathrm{K}$, Chiang S. Antioxidant properties and protein compositions of porcine haemoglobin hydrolysates. Food Chem, 2007; 100:1537-43.

Chen X, Xie N, Fang X, Yu H, Ya-mei J, Zhen-da L. Antioxidant activity and molecular weight distribution of in vitro gastrointestinal digestive hydrolysate from Flying squid (Ommastrephes bartramii) skingelatin. Food Sci, 2010; 31:123-30.

Christen Y. Oxidative stress and Alzheimer disease. Am J Clin Nutr, 2000; 71:621S-29S.

Costa E, Rezende B, Cortes S, Lemos V. Neuronal nitric oxide synthase in vascular physiology and diseases. Front Physiol, 2016; 2(7):206; doi:10.3389/fphys.2016.00206.

Davalos A, Miguel M, Bartolome B, Lopez-Fandino R. Antioxidant activity of peptides derived from egg white proteins by enzymatic hydrolysis. J Food Protection, 2004; 67:1939-44.

Davies K. An overview of oxidative stress. IUBMB Life, 2000 50(4-5):2441-44.

Donia M, Hamann M. Marine natural products and their potential applications as anti-infective agents. Lancet Infect Dis, 2003; 3(6):338-48.

Droge W. Free radicals in the physiological control of cell function. Rev Physiol Rev, 2002; 82:47-95.Hadwan M, Abed H. Data supporting the spectrophotometric method for the estimation of catalase activity. Data Brief, 2016; 6:194-9.

Halenova T, Raksha N, Savchuk O, Ostapchenko L, Prylutskyy Yu, Ritter U, Peter Scharff P. Evaluation of the biocompatibility of water-soluble pristine C60 fullerenes in rabbit. BioNanoScience, 2020; 10(3):721-30.

Halliwell B, Clement M, Long L. Hydrogen peroxide in the human body. FEBS Lett, 2000; 486(1):10-13.

Jayaprakash G, Singh R, Sakariah K. Antioxidant activity of grape seed extracts on peroxidation models in-vitro. J Agric Food Chem, 2001; 55:1018-22.

Jo HY, Jung WK, Kim SK. Purification and characterization of a novel anticoagulant peptide from marine echiuroid worm, Urechis unicinctus. Processes Biochem, 2008; 43:179-84.

Ju S, Kornienko I, Smirnova N, Pugovkina J, Ivanova M, Shilina T, Grinchuk A, Shatrova N, Aksenov V, Zenin N, Nikolsky O. High doses of synthetic antioxidants induce premature senescence in cultivated mesenchymal stem cells. Sci Rep, 2019; 9(1):1296.

Jung WK, Je JY, Kim SK. A novel anticoagulant protein from Scapharca broughtonii. J Biochem Mol Biol, 2001; 35:199-205.

Jung WK, Kim SK. Isolation and characterization of an anticoagulant oligopeptide from blue mussel, Mytilus edulis. Food Chem, 2009; 117: 687-92.

Kumar N, Nazeer R, Jaiganesh R. Purification and biochemical characterization of antioxidant peptide from horse mackerel (Megalaspis cordyla) viscera protein. Peptides, 2011; 32:1496-501.

Liu F, Ooi V, Chang S. Free radical scavenging activity of mushroom polysaccharide extracts. Life Sci, 1997; 60:763-71.

Liu J, Jin Y, Lin S, Jones G, Chen F. Purification and identification of novel antioxidant peptides from egg white protein and their antioxidant activities. Food Chem, 2015; 175:258-66.

Martins A, Vieira H, Gaspar H, Santos S. Marketed marine natural products in the pharmaceutical and cosmeceutical industries: tips for success. Mar Drugs, 2014; 12:1066-101; doi:10.3390/md12021066

Mendanha S, Anjos J, Silva A, Alonso A. Electron paramagnetic resonance study of lipid and protein membrane components of erythrocytes oxidized with hydrogen peroxide. Braz J Med Biol Res, 2012; 45:473-81.
Nikolajchik V, Moin V, Kirkovskij V. Sposob opredeleniya srednih molekul. Lab Delo, 1991; 10:13-8.

Pihlanto A. Antioxidative peptides derived from milkproteins. Int Dairy J, 2006; 16:1306-14.

Puntarulo S. Iron, oxidative stress and human health. Mol Aspects Med, 2005; 26(4-5):299-312; doi:10.1016/j.mam.2005.07.001

Rajapakse N, Jung WK, Mendis E, Moon SH, Kim SK. A novel anticoagulant purified from fish protein hydrolysate inhibits factor XIIa and platelet aggregation. Life Sci, 2005; 76:2607-19.

Raksha N, Gladun D, Savchuk O, Ostapchenko L. New fibrinogenases isolated from marine hydrobiont Adamussium colbecki. J Biochem Int, 2016a; 3(1):21-30.

Raksha N, Gladun D, Savchuk O, Ostapchenko L. Protease composition in tissue extracts of hydrobionts from Antarctic region. J Biol Nat, 2016b; 1:12-20.

Raksha N, Halenova T, Vovk T, Yurchenko A, Nikoliaeva I, Savchuk O, Ostapchenko L. Prevention of diet-induced obesity in rats by administration of peptides derived from marine hydrobiont. In: Duncan LT (ed.). Advances in health and disease. Published by Nova Science Publishers, Inc. New York, NY, vol. 11, pp 165-99, 2019.

Rice-Evans C, Miller N, Bolwell P, Bramley P, Pridham J. The relative antioxidant activities of plant-derived polyphenolic flavonoids. Free Radic Res, 1995; 22(4):375-83.

Royer M, Diouf P, Stevanovic T. Polyphenol contents and radical scavenging capacities of red maple (Acer rubrum L.) extracts. Food Chem Toxicol, 2011; 49(9):2180-88.

Safari R, Yaghoubzadeh Z. Antioxidant activity of bioactive peptides extracted from sea Cucumber (Holothuria leucospilota). Int J Pept Res Ther, 2020; 26(4):2393-98; doi:10.1007/s10989-020-10031-9

Siddhuraju P, Becker K. The antioxidant and free radical scavenging activities of processed cowpea (Vigna unguiculata L. Walp.) seed extracts. Food Chem, 2007; 101:10-9.

Silva J, Coutinho O. Free radicals in the regulation of damage and cell death - basic mechanisms and prevention. Drug Discov Ther, 2010; 4(3):144-67.

Spiegel M, Kapusta K, Kołodziejczyk W, Saloni J, Zbikowska B, Hill G, Sroka Z. Antioxidant activity of selected phenolic acids-ferric reducing antioxidant power assay and QSAR analysis of the structural features. Molecules, 2020; 25:3088; doi:10.3390/molecules25133088

Tanaka-Azevedo A, Morais-Zani K, Torquato R, Tanaka A. Thrombin inhibitors from different animals. J Biomed Biotechnol, 2010; 2010:641025; doi:10.1155/2010/641025

Varetskaya TV. Microheterogeneity of fibrinogen Cryofibrinogen. Ukr Biokhim Zhurn. 1960; 32:13-24. (in Russian)

Wang B, Wang Yu, Chi C, Luo H, Deng S, Jian-Yin Ma J. Isolation and characterization of collagen and antioxidant collagen peptides from scales of Croceine croaker (Pseudosciaena crocea). Mar Drugs, 2013; 1:4641-61; doi:10.3390/md11114641

Yildirim A, Mavi A, Kara A. Determination of antioxidant and antimicrobial activities of Rumex crispus L. extracts. J Agric Food Chem, 2001; 49:4083-89.

Yu Yu, Fan F, Wu D, Yu C, Wang Z, Du M. Antioxidant and ACE Inhibitory Activity of Enzymatic Hydrolysates from Ruditapes philippinarum. Molecules, 2018; 23(5):1189.

Zhuang Y, Zhao X, Li B. Optimization of antioxidant activity by response surface methodology in hydrolysates of jellyfish (Rhopilema esculentum) umbrella collagen. J Zhejiang Univ Sci B, 2009; 10:572-79.

How to cite this article:

Raksha N, Halenova T, Vovk T, Savchuk O, Tomchuk V, Maievska T, Ostapchenko L. Biologically active peptides derived from the Antarctic hydrobionts. J Appl Pharm Sci, 2021; 11(08):126-133. 